\title{
Acriflavine-binding Capacity Controlled by the acr $A$ Gene of Escherichia coli
}

\author{
By H. NAKAMURA* AND T. SHINYA \\ Biological Institute, Faculty of Science, Konan University, Kobe 658, Japan
}

(Received 3 October 1984)

\begin{abstract}
The acr $A$ mutation in Escherichia coli led to a substantial increase of the acriflavine-binding capacity of the cell, whereas the related mutations $\operatorname{acr} B(\mathrm{gyr} B)$ and $\operatorname{acr} C$ did not. Metal ions such as $\mathrm{Na}^{+}, \mathrm{K}^{+}, \mathrm{Mg}^{2+}, \mathrm{Ca}^{2+}$ and $\mathrm{Al}^{3+}$ effectively released the bound acriflavine, in proportion to their ionic strengths. The presence of cations, in fact, increased the survival fraction of the cells in the acriflavine-containing medium. Polymyxin B, an antibiotic which binds to membrane phospholipid, competed with acriflavine for binding sites. Cell wall digestion by treatment with lysozyme and EDTA slightly decreased the acriflavine-binding capacity. Almost no difference was observed in acriflavine-binding capacity between intact cells and cells from which lipopolysaccharide has been extracted (46.9\% removed from the $a \mathrm{cr} A$ cells and $47.4 \%$ from the acr $A^{+}$cells). Acriflavine bound to the cells was most effectively extracted by ethanol containing $1 \% \mathrm{HCl}$ or by $2 \%(\mathrm{w} / \mathrm{v})$ SDS. The difference in the acriflavine-binding capacity between the acr $A$ and $a c r A^{+}$cells was also observed in the spheroplasts. These facts indicate a relationship between the acr $A$ gene product and the acriflavine-binding capacity of the cells.
\end{abstract}

\section{INTRODUCTION}

Sensitivity of Escherichia coli to acriflavine (AF) and other basic dyes is controlled by the genetic loci $a c r A, a c r B(\operatorname{gyr} B), a c r C$ and $a c r D$ located respectively at mins $10 \cdot 6,83,4$ and near 94 on the chromosome (Nakamura, 1965, 1979a; Nakamura et al., 1978; Bachmann, 1983). The acr $A$ mutation leads to sensitivity not only to acridine and basic dyes but also to SDS, phenethyl alcohol (Nakamura, 1965, 1967, 1968), mitomycin C (Otsuji, 1968; Otsuji et al., 1972, 1978), erythromycin, lincomycin (Henson et al., 1982; Henson \& Walker, 1982), novobiocin (Coleman \& Leive, 1979) and salt hypertonicity (Nakamura, 1977; 1979b). Analysis of the composition of membrane proteins showed that the acrA mutant is deficient in a membrane protein with a molecular weight of about 60000 (referred to an $a c r A^{+}$protein), as compared with the wild-type $\left(\right.$ acr $\left.A^{+}\right)$membrane. Furthermore, observation in the electron microscope of a freeze-fracture face of the plasma membrane has demonstrated that intramembranous particles (probably proteinous complexes) of the largest class on the plasma face are lost in acrA mutants (Nakamura \& Suganuma, 1972; Nakamura et al., 1981). These results suggest that the $a c r A^{+}$ membrane protein is responsible for cellular sensitivity to AF. The $a c r A^{+}$protein has also been implicated in the stability of $F$ and $R$ plasmids in the cell (Nakamura, 1974, 1976).

The purpose of the present study was to define the AF-binding sites determined by the acr $A$ gene. It is concluded that the main sites responsible for AF binding on the cell surface are phospholipids of the plasma membrane; the presence of the $a c r A^{+}$protein decreases the binding of $\mathrm{AF}$ on the outer side of the phospholipid bilayer.

Abbreviation: AF, acriflavine. 


\section{Table 1. Bacterial strains used}

All strains used were derivatives of $E$. coli $\mathrm{K} 12$.

\begin{tabular}{ll}
\multicolumn{1}{c}{ Strain } & \multicolumn{1}{c}{ Genotype } \\
W4573 & Wild-type $\left(a c r A^{+}\right)$ \\
N43 & acr $A$ I \\
N90 & $a c r A^{+}$recombinant \\
N2310 & $a c r A^{+}$revertant \\
N2616 & acr $C I^{\text {ts }}$ \\
N2879 & acr $B$ \\
N2926 & acr $A$ acr $B$ \\
N43(pAF1) & Containing $a c r A^{+}$plasmid \\
N90(pAF1) & Containing $a c r A^{+}$plasmid
\end{tabular}

\section{METHODS}

Bacterial strains. These are listed in Table 1. Plasmid pAF1 was constructed by annealing a $2 \mathrm{~kb}$ DNA fragment containing the $a c r A^{+}$gene with the $E$. coli vector $\mathrm{pBR} 322$. Strains $\mathrm{N} 2616$, an $a c r C I^{\text {ts }}$ mutant, was resistant to $\mathrm{AF}$ at $30{ }^{\circ} \mathrm{C}$ but was sensitive to it at $43{ }^{\circ} \mathrm{C}$ (Nakamura, 1979a). It did not divide at $43{ }^{\circ} \mathrm{C}$ even in the absence of $\mathrm{AF}$.

Media. Broth medium PGY was composed of $10 \mathrm{~g}$ polypeptone (Daigo-eiyo Co., Osaka, Japan), $3 \mathrm{~g}$ yeast extract (Oriental Yeast Co., Osaka, Japan), $3 \mathrm{~g} \mathrm{NaCl}$ and $1 \mathrm{~g}$ glucose in 11 deionized water. The initial $\mathrm{pH}$ of the medium was adjusted to $\mathrm{pH} 7.4$ with $1 \mathrm{M}-\mathrm{NaOH}$. The bacteria were grown in this medium for $18 \mathrm{~h}$ at $37^{\circ} \mathrm{C}$, except for the $\mathrm{acrCl} 1^{\mathrm{ts}}$ mutant, which was grown at $30^{\circ} \mathrm{C}$.

Determination of dye-binding capacity of the cells. Freshly grown bacteria were washed once with saline $(0.85 \%$ $\mathrm{NaCl}$ solution) and then twice with distilled water. A sample of this bacterial suspension was used for determination of the dry weight, and the remainder was centrifuged and suspended in fresh PGY (pH 7.4). To samples $\left(5 \mathrm{ml}\right.$ ) of the cell suspension AF was added to obtain a final concentration of $4 \mu \mathrm{g} \mathrm{ml}^{-1}$, and the tubes were shaken for $20 \mathrm{~min}$ at $37^{\circ} \mathrm{C}$. The cells were then separated by centrifugation $(12500 \mathrm{r}$.p.m., $13000 \mathrm{~g}$, for $10 \mathrm{~min}$ at $5{ }^{\circ} \mathrm{C}$ ), and the AF contents of the supernatants were determined with a spectrophotometer (Hitachi, model 124) at $450 \mathrm{~nm}$. The AF-binding capacity of the cells relative to the dry weight was calculated from the AF content of the supernatants. The control did not contain cells. The centrifugation temperature was maintained carefully since it had been shown previously that cooling of the culture to $0{ }^{\circ} \mathrm{C}$ rapidly increased the AF-binding capacity of cells (Nakamura, 1966).

Extraction of lipopolysaccharide from cells by EDTA treatment. The procedure for lipopolysaccharide (LPS) extraction from the cells was basically as described by Leive (1968). Freshly grown bacteria were washed once with saline and once with distilled water, and were resuspended in distilled water. Tris/ $\mathrm{HCl}$ buffer $(\mathrm{pH} 8.0)$ was added to a final concentration of $0.12 \mathrm{M}$ and the suspension was centrifuged $\left(6000 \mathrm{r}\right.$.p.m., $3000 \mathrm{~g}$, for $10 \mathrm{~min}$ at $\left.5^{\circ} \mathrm{C}\right)$. The cells were suspended in $0.12 \mathrm{M}$-Tris $/ \mathrm{HCl}$ buffer $(\mathrm{pH} 8.0)$ prewarmed at $37^{\circ} \mathrm{C}$, and an EDTA solution $(\mathrm{pH} \mathrm{8.0)}$ was added to give a final concentration of $15 \mathrm{mM}$. After stirring gently for $5 \mathrm{~min}$ at $37^{\circ} \mathrm{C}, \mathrm{a} \mathrm{CaCl}_{2}$ stock solution was added to a final concentration of $40 \mathrm{~mm}$ to stop the effect of EDTA. After extraction of LPS the cells were centrifuged at 10000 r.p.m. $(8500 \mathrm{~g})$ for $20 \mathrm{~min}$ at $5^{\circ} \mathrm{C}$ and washed once with saline for use in the AF binding experiment.

Determination of LPS content. The LPS content of the EDTA-extracted and the control (not extracted) cells was determined by the method of Westphal \& Jann (1955). Cells of strains N43 and N90 were each suspended in $4 \mathrm{ml}$ distilled water prewarmed at $70{ }^{\circ} \mathrm{C}$, and $5 \mathrm{ml} 90 \%(\mathrm{v} / \mathrm{v})$ phenol solution at $70^{\circ} \mathrm{C}$ was added. After $5 \mathrm{~min}$, they were cooled to $10^{\circ} \mathrm{C}$ on ice and centrifuged at 3000 r.p.m. $(750 \mathrm{~g})$ for $10 \mathrm{~min}$ at $5{ }^{\circ} \mathrm{C}$. The resulting aqueous layer was carefully removed with an L-form pipette, and the remaining fraction was again extracted with $5 \mathrm{ml}$ of water at $70{ }^{\circ} \mathrm{C}$. The aqueous extracts were combined and centrifuged again. The supernatant was then dialysed against distilled water until the smell of phenol had disappeared. The dialysed sample was centrifuged to 40000 r.p.m. $(140000 \mathrm{~g})$ for $120 \mathrm{~min}$ at $2{ }^{\circ} \mathrm{C}$. The pellet was washed with a small amount of distilled water, and was analysed as the LPS fraction.

The LPS content was estimated as 2-keto-3-deoxyocturonic acid (KDO), a component of LPS (Osborn, 1963), with deoxyribose as standard. Protein was estimated by the method of Lowry.

Preparation of spheroplasts. Fresh PGY culture $(80 \mathrm{ml})$ was centrifuged. The cells were washed twice with $10 \mathrm{mM}$-Tris $/ \mathrm{HCl}(\mathrm{pH} 8.0)$ and were resuspended in $30 \mathrm{ml}$ of ice-cold $0.3 \mathrm{M}$-sucrose $/ 10 \mathrm{~mm}$-Tris/ $/ \mathrm{HCl}(\mathrm{pH} 8.0)$. EDTA and egg-white lysozyme (Sigma) were each added to a final concentration of $100 \mu \mathrm{g} \mathrm{ml}^{-1}$. The suspension was kept on ice for $15 \mathrm{~min}$ and centrifuged at $12000 \mathrm{r}$ r.p.m. $(12000 \mathrm{~g})$ for $15 \mathrm{~min}$ at $5{ }^{\circ} \mathrm{C}$, and the sediment was washed once with $0.3 \mathrm{M}$-sucrose $/ 10 \mathrm{~mm}-\mathrm{Tris} / \mathrm{HCl}(\mathrm{pH} 8.0)$ to remove the reagents. Observation under the light microscope showed that the morphology of the cells was changed completely to spheroplasts (a round shape) by this procedure. The colony-forming ratio of the spheroplast fraction was less than $10^{-4}$. 
RESULTS

Genetic control of the AF-binding capacity of the cells

When an AF-resistant $\left(a c r A^{+}\right) \mathrm{Hfr} C$ strain was crossed with the AF-sensitive (acr $A$ ) strain $\mathrm{N} 43$ and selected for $\mathrm{lac}^{+} \mathrm{met}^{+}$and $\mathrm{ara}^{+} \mathrm{met}^{+}$, the AF-sensitive recombinants among them bound AF [22-24 $\mu \mathrm{g}$ (mg dry wt) $\left.)^{-1}\right]$ twice as much as the AF-resistant recombinants (Nakamura, 1966). The purpose of the experiments described in this paper was to investigate the effect of the other AF sensitivity mutations, $a c r B$ and $a c r C$, on the AF-binding capacity of the cells.

First, the AF-binding capacity was compared among strains N43, N90, N2310, N43(pAF1) $\left(a c r A^{+} / a c r A\right)$ and $\mathrm{N} 90(\mathrm{pAF} 1)\left(a c r A^{+} / a c r A^{+}\right)$. The introduction of $a c r A^{+}$gene(s) into N43 by conjugation (N90), plasmid transformation [N43(pAF1) and N90(pAF1)] and true reversion of acr $A$ to $a c r A^{+}(\mathrm{N} 2310)$ decreases the AF-binding capacity of cells to the level of the wild-type strain (W4573; Fig. 1.). Interestingly, an increase of the $a c r A^{+}$gene dose seems to diminish the AF-binding capacity of the host cell, as shown in strains N43(pAF1) and N90(pAF1). The cloned $a c r A^{+}$plasmid and the $\mathrm{F}^{\prime}\left(\mathrm{F}_{13}\right)$ plasmid containing the $a c r A^{+}$gene significantly increased the $\mathrm{AF}$ resistance of their host cells (data not shown).

Secondly, the effect of the $a c r B$ mutation on the AF-binding capacity was investigated. The $a c r B$ mutant (N2879) was less sensitive to AF than the $a c r A$ mutant (N43). The $a c r A a c r B$ double mutant (N2926) was much more sensitive to AF than either of the single mutants (Nakamura et al., 1978). Though the $a c r B$ mutant had increased AF-binding capacity, the level was $65 \%$ of that of the acr $A$ mutant. Furthermore, the acr $A$ acr $B$ double mutant bound $81 \%$ AF when compared with the acr $A$ strain. Thus the amount bound was intermediate between the amounts for the $a c r A$ and $a c r B$ single mutants.

Finally, the AF-binding capacity of the $\operatorname{acr} C$ mutant (N2616) was investigated. Freshly grown cells of strains N2616 and N43, after washing the saline and distilled water, were suspended in

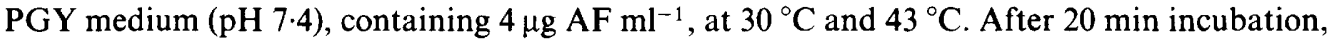
the AF-binding capacity of cells was determined. No difference was found in the AF-binding capacity of the strains or between the incubation temperatures.

\section{Effect of various salts on the AF binding of cells}

AF taken up by $E$. coli cells is not incorporated in the cytoplasm but is adsorbed on the cell surface (Nakamura, 1966; Silver et al., 1968). Therefore the position of the AF-binding site(s) on the envelope structure of the cell was investigated.

First, the effect of washing $a c r A$ and $a c r A^{+}$cells with saline $(0.85 \% \mathrm{NaCl})$ and distilled water (control) was studied. The cells were incubated in PGY medium containing $4 \mu \mathrm{g} \mathrm{AF} \mathrm{ml} \mathrm{for}^{-1}$ for $20 \mathrm{~min}$ at $37^{\circ} \mathrm{C}$, and were washed one to five times with $5 \mathrm{ml}$ of either the saline or distilled water. The bound AF was released markedly $(50 \%)$ by several washes with saline, but not with water (Fig. 2). However, when the $\mathrm{NaCl}$ concentration of the washes was increased to $500 \mathrm{~mm}$, the AF bound to cells decreased by $66 \%$ (per dry wt) for strain N43 and $72 \%$ for strain N90.

Secondly, the dependence of dissociation of AF on charge number and ionic strength of metal ions in the washing solution was determined. The $\mathrm{N} 43$ and $\mathrm{N} 90$ cells treated with $4 \mu \mathrm{g} \mathrm{AF} \mathrm{ml}^{-1}$, as described above, were resuspended in $5 \mathrm{ml}$ solutions of $\mathrm{NaCl}, \mathrm{KCl}, \mathrm{MgCl}_{2}, \mathrm{CaCl}_{2}$ and $\mathrm{AlCl}_{3}$ at various concentrations. They were immediately centrifuged at 15000 r.p.m. $(18000 \mathrm{~g})$ for $5 \mathrm{~min}$ at $5{ }^{\circ} \mathrm{C}$. Divalent and trivalent cations dissociated AF from both strains more efficiently than monovalent cations (Fig. 3). AF was released proportionally with rising of the ionic strength for the divalent and trivalent cations, while for the monovalent cations, the release of AF increased rapidly at ionic strengths over $0 \cdot 05$.

\section{Effect of salt on cellular sensitivity to $A F$}

The effect of salts on survival of cells in the presence of AF was investigated. Fresh cultures of strains N43 and N90 were pipetted into test tubes containing $5 \mathrm{ml}$ of media which consisted of $5 \mathrm{~g}$ polypeptone and $1 \mathrm{~g}$ yeast extract in 11 deionized water $(\mathrm{pH} \mathrm{8.5)}$. The media also contained $5 \mu \mathrm{g} \mathrm{AF} \mathrm{ml}^{-1}$ and various concentrations of $\mathrm{NaCl}, \mathrm{KCl}, \mathrm{MgCl}_{2}$ or $\mathrm{CaCl}_{2}$. Survival curves for 


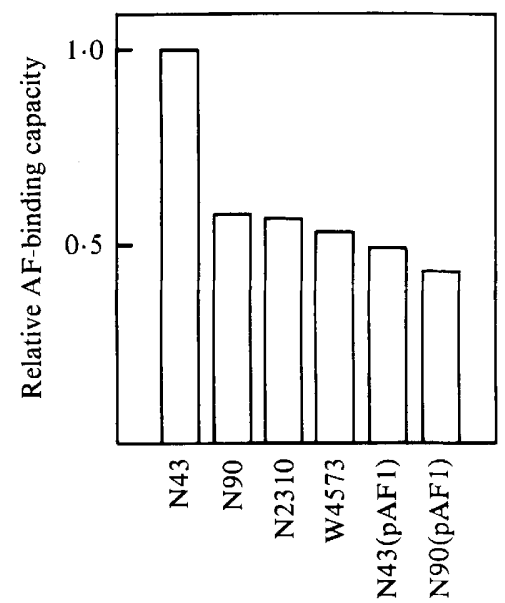

Fig. 1

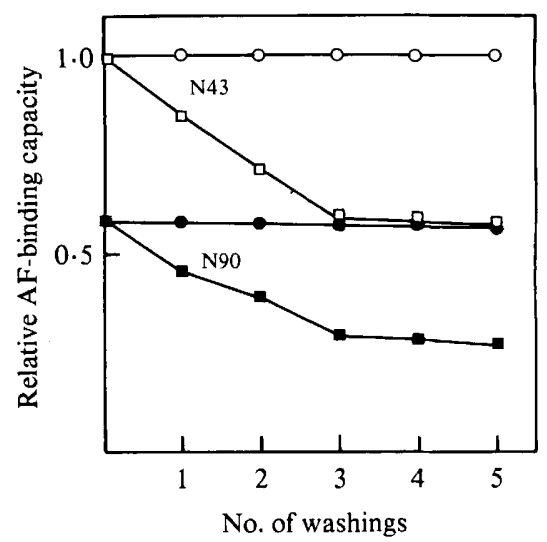

Fig. 2

Fig. 1. AF-binding capacities of $E$. coli strains $\mathrm{N} 43$ (acr $A), \mathrm{N} 90\left(\right.$ acr $A^{+}$recombinant), $\mathrm{N} 2310$ ( $a c r A^{+}$ true revertant from $\mathrm{N} 43$ ), W4573 (wild-type, acr $A^{+}$), N43(pAF1) (acr $A^{+} / a c r A$, containing cloned plasmid) and $\mathrm{N} 90\left(\mathrm{pAF}\right.$ ) ( $\mathrm{acr} \mathrm{A}^{+} / \mathrm{acr} \mathrm{A}^{+}$, containing cloned plasmid). The relative AF-binding capacity of the cells was calculated from the AF bound per mg dry weight; the value was $22-24 \mu \mathrm{g}(\mathrm{mg} \text { dry wt })^{-1}$ for N43. The data in this and following figures are means of three parallel experiments, and the SD was within $30 \%$ of the mean.

Fig. 2. AF-binding capacities of E. coli strains N43 (open symbols) and N90 (filled symbols) on repeated washing with distilled water (circles) or saline $(0.85 \% \mathrm{NaCl}$; squares).

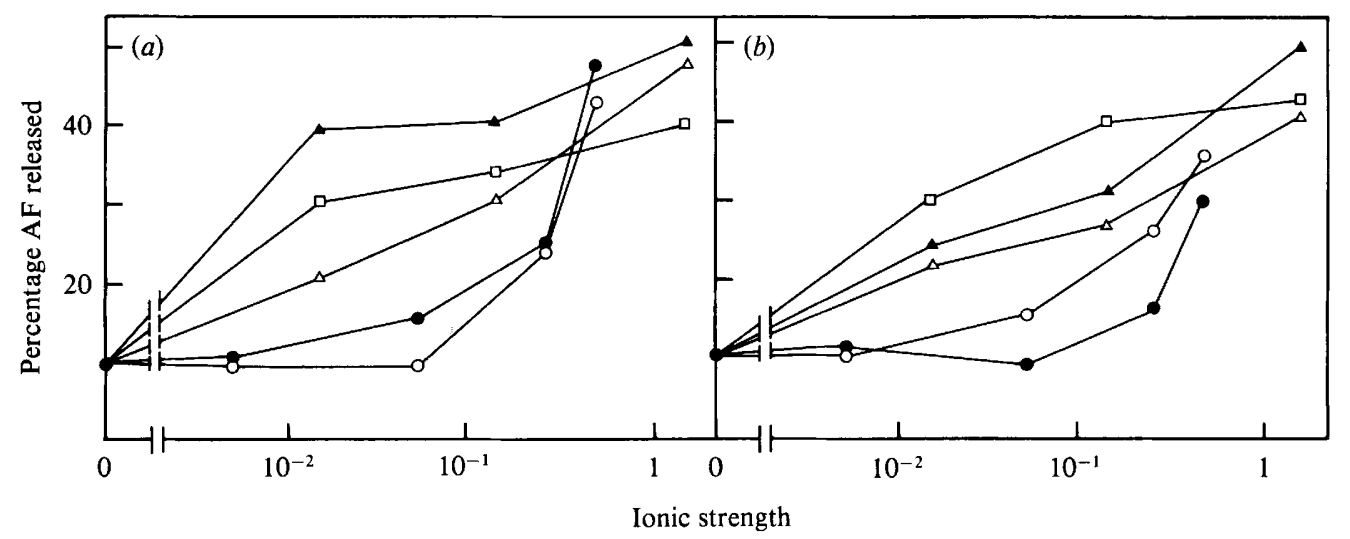

Fig. 3. Effect of washing with various ionic strengths of salt solutions on AF release from AF-treated cells of $E$. coli strains $(a) \mathrm{N} 43$ and $(b) \mathrm{N} 90$. The washing solution contained $\mathrm{NaCl}(\mathrm{O}), \mathrm{KCl}(\mathrm{O}), \mathrm{MgCl}_{2}$ $(\triangle), \mathrm{CaCl}_{2}(\mathbf{\Delta})$ or $\mathrm{AlCl}_{3}(\square)$.

the cells after $2 \mathrm{~h}$ incubation at $37^{\circ} \mathrm{C}$ are shown in Fig. 4. The survival fraction of strain N43 increased rapidly in the presence of more than $350 \mathrm{~mm}-\mathrm{NaCl}$ and in $860 \mathrm{~mm}-\mathrm{NaCl}$ reached the value of strain N90 (Fig. 4a). Salt marginally increased the survival of N90 in the AF medium but the effect was not concentration-dependent. For $\mathrm{KCl}$, the survival fraction of strain $\mathrm{N} 43$ increased gradually with concentrations of $\mathrm{KCl}$ of more than $31 \mathrm{mM}$ (Fig. $4 b$ ). Strain N90 became more tolerant to $\mathrm{AF}$ in $\mathrm{KCl}$ concentrations of over $125 \mathrm{~mm}$. On the other hand, the effect of $\mathrm{MgCl}_{2}$ was more marked; the survival fraction of strain $\mathrm{N} 43$ reached a maximal level of $10^{-1}$ in the presence of $31 \mathrm{mM}-\mathrm{MgCl}_{2}$ (Fig. $4 c$ ). Strain $\mathrm{N} 90$ was also more tolerant to AF in the presence of $\mathrm{MgCl}_{2}$, but high concentrations of the salt were toxic to the strain. The same trends were also observed for $\mathrm{CaCl}_{2}$; survival of strain $\mathrm{N} 43$ increased sharply in concentrations greater than $31 \mathrm{~mm}$, and that of strain $\mathrm{N} 90$ also increased at levels greater than $63 \mathrm{~mm}$ (Fig. $4 d$ ). 

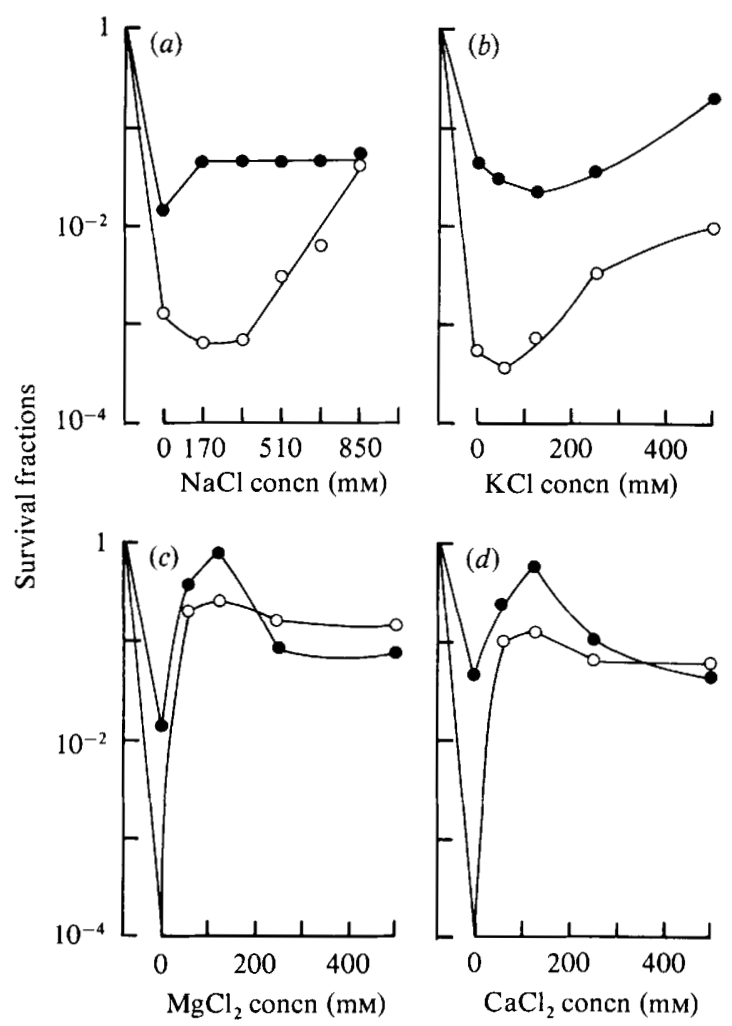

Fig. 4. Effect of (a) $\mathrm{NaCl},(b) \mathrm{KCl},(c) \mathrm{MgCl}_{2}$ and (d) $\mathrm{CaCl}_{2}$ concentrations on the survival of cells in medium containing $5 \mu \mathrm{m} \mathrm{AF} \mathrm{ml}{ }^{-1}$. The survival fraction was determined after incubation for $2 \mathrm{~h}$ at $37^{\circ} \mathrm{C}$. E. E. coli $\mathrm{N} 90 ; \mathrm{O}$, E. coli $\mathrm{N} 43$.

However, higher concentrations of $\mathrm{CaCl}_{2}$ were harmful to both strains. Although the same type of test was done for $\mathrm{AlCl}_{3}$, precipitation occurred in the media under the conditions used (data not shown).

\section{Competition of $A F$ with polymyxin $B$}

It was concluded from above that AF probably bound to negatively charged site(s) on the cell envelope, and thus the bound AF was exchangeable with metal ions. Other results indicated that an increase of hydrogen ion concentration effectively released AF from the AF-treated cells; complete dissociation of AF was achieved by washing with highly acidic solutions (unpublished). Therefore, the next approach was to examine whether AF competed with polymyxin B. Polymyxin B is a cationic peptide antibiotic possessing a broad range action spectrum against Gram-negative bacteria (Sud \& Feingold, 1971), and it binds to phosphoric sites of the phospholipid molecules of the cell wall and plasma membrane to express its antibiotic activity (Imai et al., 1975; Teuber \& Bader, 1976a, b).

Freshly grown cells of strains N43 and N90 were washed once with saline and twice with distilled water, and were resuspended in fresh PGY medium. The culture was divided into six tubes ( $5 \mathrm{ml}$ in each), and $4 \mu \mathrm{g} \mathrm{AF} \mathrm{ml}{ }^{-1}$ and various concentrations $\left(10-1000 \mu \mathrm{g} \mathrm{ml}^{-1}\right.$ ) of polymyxin $\mathrm{B}$ were added. After shaking for $20 \mathrm{~min}$ at $37^{\circ} \mathrm{C}$ and centrifugation at 12500 r.p.m. $(13000 \mathrm{~g})$ for $10 \mathrm{~min}$ at $5^{\circ} \mathrm{C}$, the $\mathrm{AF}$ contents of the supernatants were determined photometrically. There was competition between $\mathrm{AF}$ and polymyxin $\mathrm{B}$ molecules for the negatively charged sites. (Fig. 5). The effect of polymyxin B in decreasing bound AF was more pronounced in strain N43 than in strain N90. 


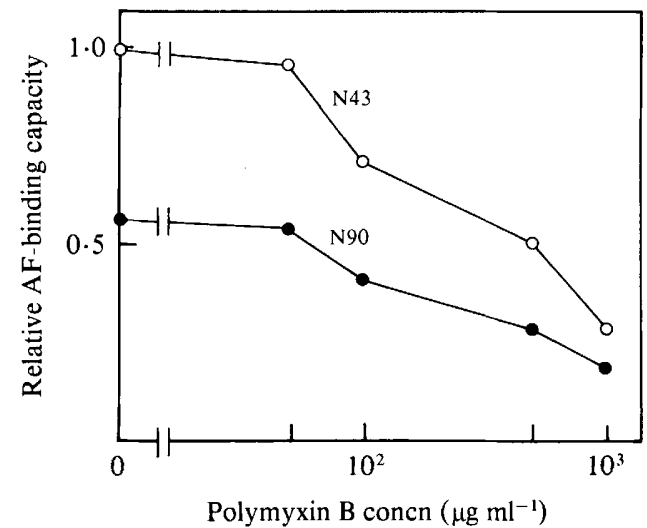

Fig. 5

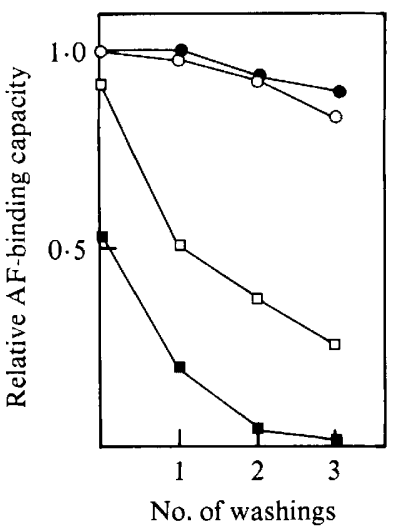

Fig. 6

Fig. 5. Competition between AF and polymyxin B for binding sites. Various concentrations of polymyxin B were added to media containing $4 \mu \mathrm{g} \mathrm{AF} \mathrm{ml}^{-1}$ which was then incubated for $20 \mathrm{~min}$ at $37^{\circ} \mathrm{C}$. O, E. coli $\mathrm{N} 90 ; \mathrm{O}$, E. coli $\mathrm{N} 43$.

Fig. 6. AF-binding capacities of AF-treated spheroplasts of E. coli strains N43 (open symbols) and N90 (filled symbols) on repeated washing with $0.3 \mathrm{M}$-sucrose (circles) or saline containing $0.3 \mathrm{M}$-sucrose (squares).

\section{Comparison of AF-binding capacity between intact cells and spheroplasts}

To determine the distribution of AF-binding sites on the cell wall and plasma membrane, fresh, spheroplasts of strains $\mathrm{N} 43$ and $\mathrm{N} 90$ and their intact cells were used. The spheroplasts and intact cells were suspended in the hypertonized Tris/ $\mathrm{HCl}$ solution containing $4 \mu \mathrm{g} \mathrm{AF} \mathrm{ml} l^{-1}$ and after 20 min incubation at $37^{\circ} \mathrm{C}$, the AF-binding capacity was determined. The AF bound was compared per unit of protein. For both strains, AF binding capacity of spheroplasts was lower than that of intact cells $(59-88 \%)$. However, it must be stressed that the major sites for the AF binding seem to be on the plasma membrane, rather than on the cell wall. In a control experiment, no lysis of the spheroplasts was observed even by treatment with $100 \mu \mathrm{g} \mathrm{AF} \mathrm{ml} \mathrm{m}^{-1}$ for $90 \mathrm{~min}$.

To examine the possibility of LPS as the AF-binding site, cells of strains N43 and N90 from which LPS had been extracted were prepared as described in Methods and tested for their AFbinding capacity. Acccording to our procedure for LPS extraction, 46.9\% and $47.4 \%$ LPS were removed from the cells of strains N43 and N90 respectively. However, the extraction did not reduce the AF-binding capacity of either strain (data not shown).

AF release from the AF-treated spheroplasts was compared in $0.3 \mathrm{M}$-sucrose and in saline containing $0.3 \mathrm{M}$-sucrose. The bound $\mathrm{AF}$ was more effectively released when $\mathrm{NaCl}$ was present (Fig. 6). Furthermore, the AF released by the $0.3 \mathrm{M}$-sucrose saline washing of AF-treated spheroplasts was more pronounced than release of AF by saline in the AF-treated intact cells (Figs 2 and 6).

The role of the plasma membrane as the AF-binding site was also investigated. Cells of strains $\mathrm{N} 43$ and $\mathrm{N} 90$ were routinely treated with $\mathrm{AF}$ and suspended in $0.3 \mathrm{M}$-sucrose $/ 10 \mathrm{~mm}$-Tris/ $\mathrm{HCl}$ (pH 8.0) containing $100 \mu \mathrm{g}$ EDTA ml ${ }^{-1}$ or $100 \mu \mathrm{g}$ lysozyme $\mathrm{ml}^{-1}$, or both. Only small amounts of AF were released by treatment with lysozyme plus EDTA; binding ranged from 77 to $81 \%$ of that obtained with the AF-treated bacteria. This is good evidence that digestion of the cell wall of the AF-treated cells has no major effect on AF-binding capacity.

The results shown above suggest that the major site of AF binding is the plasma membrane, rather than the cell wall. Therefore, we examined an interaction of AF and phosphatidylethanolamine (PE), a main component of membrane phospholipids. PE from sheep brain lipid was dissolved in chloroform in a final concentration of $0.25 \mathrm{~mm}$ and warmed to $37^{\circ} \mathrm{C}$. An aqueous AF solution $(0.01 \mathrm{mM})$ at $37^{\circ} \mathrm{C}$ was mixed well with the PE solution. After incubation for $20 \mathrm{~min}$ with vigorous agitation, the mixture was centrifuged at 3000 r.p.m. (750 g) for $10 \mathrm{~min}$. A 


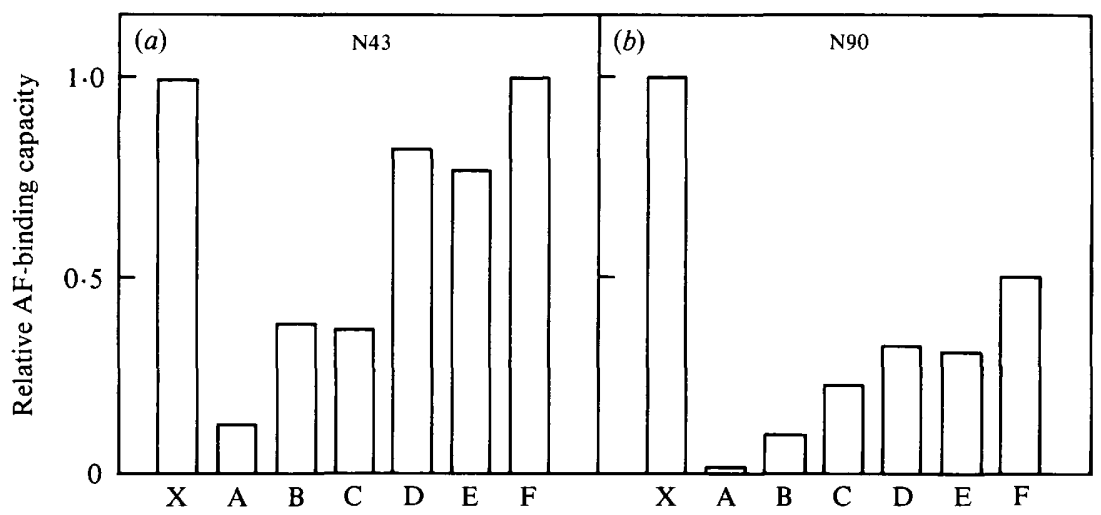

Fig. 7. AF-binding capacities of AF-treated cells of $E$. coli strains (a) N43 and $(b) \mathrm{N} 90$ after treatment with (A) $1 \% \mathrm{HCl} / \mathrm{ethanol}$, (B) $2 \%(\mathrm{w} / \mathrm{v}) \mathrm{SDS}$, (C) acetone, (D) saline, (E) boiling saline and (F) toluene or chloroform. The control (X) was not treated.

substantial amount of AF was shown to transfer from the water to the chloroform layer, while a little AF moved into a PE-free chloroform layer (control experiment). This result shows that an AF-PE complex forms which is lipophilic. However, when the PE solution was pretreated with $\mathrm{NaCl}$ solution or when the AF solution contained $\mathrm{NaCl}$, much less $\mathrm{AF}$ was transferred into the PE layer.

\section{AF extraction by various solvents}

Cells of N43 and N90 were freshly grown in $80 \mathrm{ml} \mathrm{PGY} \mathrm{medium} \mathrm{(pH} \mathrm{7.4),} \mathrm{and} \mathrm{after} \mathrm{washing}$ twice with distilled water, were suspended in PGY medium ( $\mathrm{pH} \mathrm{7.4)} \mathrm{containing} 4 \mu \mathrm{g} \mathrm{AF} \mathrm{ml}^{-1}$. After shaking for $20 \mathrm{~min}$ at $37^{\circ} \mathrm{C}$, the cells were centrifuged and resuspended in $5 \mathrm{ml}$ of the following solvents: (1) ethanol containing $1 \% \mathrm{HCl},(2) 2 \%(\mathrm{w} / \mathrm{v}) \mathrm{SDS}$, (3) acetone, (4) saline $(0.85 \% \mathrm{NaCl}$ solution), (5) boiling saline and (6) toluene or chloroform. After stirring well, the cell suspensions were centrifuged at 12500 r.p.m. $(13000 \mathrm{~g})$ for $5 \mathrm{~min}$ at $5{ }^{\circ} \mathrm{C}$, and the $\mathrm{AF}$ contents of the supernatants were determined. Ethanol containing $1 \% \mathrm{HCl}$, and $2 \%$ SDS were most effective at reducing the AF-binding capacity of cells, as compared with other solvents (Fig. 7). This suggests that compounds which disorganize membrane lipid bilayers are also effective extractants of AF.

\section{DISCUSSION}

The acr $A$ mutant takes up significantly more AF than the wild-type $\left(a c r A^{+}\right)$cell. However, it has been demonstrated kinetically that the uptake of AF is due to binding on the cell surface and not due to incorporation into cytoplasm (Nakamura, 1966; Silver et al., 1968). The AF binding occurs very rapidly and has no lag time. The present study showed that the AF-binding capacity of the $E$. coli cell is most effectively determined by the $a c r A$ gene as compared with $\operatorname{acr} B(\operatorname{gyr} B)$ and $a c r C$.

The present data strongly suggest that the AF-binding sites are on the plasma membrane. Although the phospholipids are also a component constituting the bacterial cell wall, experiments inducing LPS extraction, spheroplast formation, digestion of the walls of the AFtreated cells and some others seem to show that the cell wall only plays a minor role in AF binding. The plasma membrane is primarily composed of a phospholipid bilayer, and the structure presents a barrier to permeant substances. AF is a cationic dye and thus must be unable to pass through the hydrophobic phase. Also, AF does not seem to be incorporated by using a carrier. Therefore, it is reasonable to assume that the AF molecule binds to a negatively charged site, probably phosphate, of the outer side of the phospholipid bilayer. 
How does the acr $A$ gene control the AF-binding capacity of the cell? We have already shown that the acr $A$ mutation leads to a loss of $a c r A^{+}$protein (molecular weight 60000 ) in the plasma membrane (Nakamura et al., 1982). Observation in the electron microscope of a freeze-fracture face of the membrane has also shown that the largest class of the intramembranous particles is lost from the acr $A$ mutant membrane, and that the non-particle area of the mutant membrane is increased by $34 \%$ as compared to the wild-type membrane (Nakamura et al., 1981). Moreover, in the acrA mutant, a considerable lamellar structure is formed in the presence of low concentrations of AF but not in the $a c r A^{+}$strain (Nakamura et al., 1982). Furthermore, it appears unlikely that certain membrane protein(s) have a specific affinity to AF, since no difference in the AF-staining intensity is found among the proteins separated by acrylamide gel electrophoresis. Thus, we are led to the conclusion that the area responsible for the AF-binding capacity of the plasma membrane is mainly the phospholipid region, and that the acr $A$ mutation leads to an increase in binding through the loss of the acr $A^{+}$protein.

We thank Mr Y. Nakayama for his technical help.

This work was supported by a grant (to H.N.) from the Ministry of Education, Science and Culture of Japan.

\section{REFERENCES}

BaChMaNN, B. J. (1983). Linkage map of Escherichia coli. Microbiological Reviews 47, 180-230.

Coleman, W. G., JR \& Leive, L. (1979). Two mutations which affect the barrier function of Escherichia coli. Journal of Bacteriology 139, 899-910.

Henson, J. A. \& Walker, J. R. (1982). Genetic analysis of acrA and lir mutations of Escherichia coli. Journal of Bacteriology 152, 1301-1302.

Henson, J. A., Blinkowa, A. \& Walker, J. R. (1982). The Escherichia coli dna $W$ mutation is an allele of the adk gene. Molecular and General Genetics 186, 488492.

ImaI, M., INoue, K. \& Nozima, S. (1975). Effect of polymyxin $\mathrm{B}$ on liposomal membrane derived from Escherichia coli lipids. Biochimica et biophysica acta 375, 130-137

LEIVE, L. (1968). Studies on the permeability change produced in coliform bacteria by ethylenediaminetetraacetate. Journal of Biological Chemistry 243, 2372-2380.

NAKAMURA, H. (1965). Gene-controlled resistance to acriflavine and other basic dyes in Escherichia coli. Journal of Bacteriology 90, 8-14.

NAKAMURA, H. (1966). Acriflavine-binding capacity of Escherichia coli in relation to acriflavine sensitivity and metabolic activity. Journal of Bacteriology $\mathbf{9 2}$, 1447-1452.

NaKamura, H. (1967). Phenethyl alcohol sensitivity in Escherichia coli. Journal of Bacteriology 93, 11831184.

NAKAMURA, H. (1968). Genetic determination of resistance to acriflavine, phenethyl alcohol and sodium dodecylsulfate in Escherichia coli. Journal of Bacteriology 96, 987-996.

NaKamura, H. (1974). Plasmid instability in acr $A$ mutants of Escherichia coli K12. Journal of General Microbiology 84, 85-93.

NAKAMURA, H. (1976). $R$ factor instability in the acriflavine-sensitive mutant of Escherichia coli K-12. Japanese Journal of Genetics 51, 393-395.

NAKAMURA, H. (1977). Genetic determination of sensitivity to salt hypertonicity in Escherichia coli. Journal of General Microbiology 102, 221-222.
NaKamura, H. (1979a). Novel acriflavine resistance genes, acrC and acrD, in Escherichia coli K 12. Journal of Bacteriology 139, 8-12.

NAKamURA, H. (1979b). Specific proline accumulation in an acrA mutant of Escherichia coli $\mathrm{K} 12$ grown in salt-hypertonic medium. Journal of General Microbiology 113, 425-427.

Nakamura, H. \& Suganuma, A. (1972). Membrane mutation associated with sensitivity to acriflavine in Escherichia coli. Journal of Bacteriology 110, 329335.

Nakamura, H., Hachiya, N. \& Tojo, T. (1978). Second acriflavine sensitivity mutation, $a c r B$, in Escherichia coli K12. Journal of Bacteriology 134, 1184-1187.

Nakamura, H., Yokomura, E., Hase, A. \& SuganUMA, A. (1981). A plasma membrane mutation acr A in Escherichia coli. Plant and Cell Physiology 22, 1141-1148.

Nakamura, H., Yokomura, E. \& Hirayoshi, K. (1982). Effect of acriflavine on the plasma membrane of Escherichia coli K-12. Plant and Cell Physiology 128, 3067-3070.

OSBORN, M. J. (1963). Studies on the gram-negative cell wall. I. Evidence for 2-keto-3-deoxyoctonate in the lipopolysaccharide of Salmonella typhimurium. Proceedings of the National Academy of Sciences of the United States of America 50, 499-506.

Otsuj, N. (1968). Properties of mitomycin C-sensitive mutants of Escherichia coli K-12. Journal of Bacteriology 95, 540-545.

Otsuji, N., Higata, T. \& Kawamata, J. (1972). Genetic and physiological analysis of mytomycin Csensitive mutants of Esherichia coli K-12. Biken Journal 15, 45-49.

Otsuji, N., HoRiuchi, T., Nakata, A. \& Kawamata, J. (1978). Studies of Escherichia coli hypersensitive to representative carcinostatic and carcinogenic agents. Journal of Antibiotics 31, 794-796.

Silver, S., Levine, E. \& Spielman, P. M. (1968). Acridine binding by Escherichia coli: $\mathrm{pH}$ depen. dency and strain differences. Journal of Bacteriology 95, 333-339. 
Sud, I. J. \& FEINGoLD, D. S. (1971). Mechanism of polymyxin B sensitivity in Proteus mirabilis. Journal of Bacteriology 104, 289-294.

TEUBER, M. \& BADER, J. (1976a). Action of polymyxin $B$ on bacterial membranes: binding capacities for polymyxin B of inner and outer membranes isolated from Salmonella typhimurium G30. Archives of Microbiology 109, 51-58.
Teuber, M. \& Bader, J. (1976 b). Action of polymyxin $B$ on bacterial membranes: phosphatidylglycerol and cardiolipin-induced susceptibility to polymxyin B in Acholeplasma laidlawii B. Antimicrobial Agents and Chemotherapy 9, 26-35.

WESTPHAL, O. \& JANN, K. (1955). Extraction with phenol-water and further applications of the procedure. Methods in Carbohydrate Chemistry 5, 83-91. 